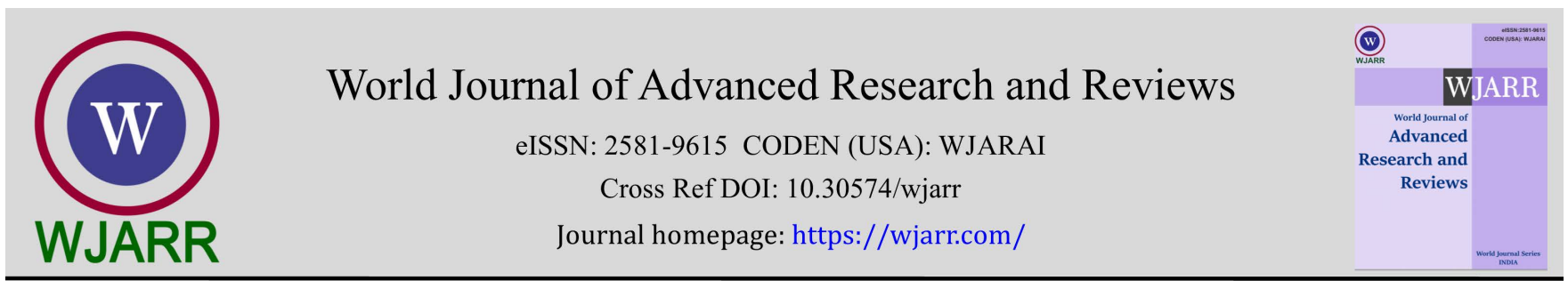

(RESEARCh ARTICLE)

\title{
Statistical analysis on bio-efficacy of different solvent fraction of Andrographis paniculata against some bacteria
}

\author{
Olawale Kolapo Steve Emiola *, Musibau Abayomi Omoloye and Anietie Edem Udokang \\ Department of Statistics, Federal Polytechnic, Offa, Kwara State, Nigeria.
}

World Journal of Advanced Research and Reviews, 2021, 12(01), 473-480

Publication history: Received on 19 September 2021; revised on 27 October 2021; accepted on 29 October 2021

Article DOI: https://doi.org/10.30574/wjarr.2021.12.1.0546

\begin{abstract}
This research is concentrated on the Statistical Analysis of antimicrobial activity of different solvent extract of Andrographis paniculata leaves on bacterial that cause diseases. And it was aimed to compare the effect of Andrographis paniculata on some selected bacteria with the normal antibiotics. The bacterial isolates used in the study were Staphylococcuc aurcus, Streptococcus pyogens, Proteus vulgaris and Escherichia coli. The data was collected by experimental method from laboratory as source of primary data. Randomized complete block design with two-way analysis of variance were used to analyze the data in order to determine the significant difference in efficacy of fractions solvent extract of Andrographis paniculata leaves on bacteria. The normal antibiotics used are: Streptomycin, Gentamycin, Amoxillin, Chloramphenicol, Contrimoxazole, ofloxaacin, Erthrommycin, ERX, PT and Ceftriaxone. MINITAB 16 statistical software were used for computation analysis of the data collected. The result of the analysis reveal that there is significant difference in the efficacy of different antibiotics on bacteria that cause diseases. Although it was observed that the level of inhibition of each antibiotics were not the same but they all possess antibicteria properties that could be used to treat some bacteria diseases. Therefore, it was concluded that Andrographis paniculata is highly potent in the treatment of some selected bacterial diseases. I hereby recommended that, the effective drugs could be produced from Andrographis paniculata leaves used in traditional medicine, thereby enhance self-reliance, more active drugs can be produced to solve the present-day problems of drug resistance in the health management.
\end{abstract}

Keywords: Andrographis paniculata; Antibiotics; ANOVA; Bacteria; Treatment

\section{Introduction}

Andrographis paniculata leaf is an herbaceous plant, commonly known as king of bitters" in the family Acanthaceae. It is widely cultivated in southern Asia, mostly the leaves and roots have been traditionally used over the centuries for different medicinal purposes in Asia and Europe as a forklore remedy for a wide spectrum of ailments or as an herbal supplement for health promotion Anurag et al. [1], Ayak et al. [3], Dada et al. [8]. Anial et al. [2], Rajalakshmi et al. [10], Tapsel et al. [21] worked on the aerial parts of the plants (leaves and stems) are used to extract the active phytochemicals. It shows previous investigations on the chemical composition of the Andrographis develop antimicrobial compounds with the isolated compounds or their synthetic analogues and the present investigation study the antibacterial potential of extract of Antigraphis paniculata against selective human pathogens. Singha and Roys [20] Reported that crude powder suspended in water had no invitro antibacterial activity against salmonella, shigella, Eschericia-coli and Staphylococcus aureus, even at a concentration of $25 \mathrm{mg} / \mathrm{ml}$ crude powder. The same result was reported by Liu et al. [12], Parvataneni and Koduru [14] who found crude aqeous extract of leaves had no activity against Eschericia coli or klebsiella pneumonia but exhibited significant antimicrobial activity against gram positive aureus, methicilin-resistant Staphylococcus aureus (MRSA), and gram-negative Pseudomonas aeruginosa. Pholphana et al. [15],

\footnotetext{
${ }^{*}$ Corresponding author: Olawale Kolapo Steve Emiola

Department of Statistics, Federal Polytechnic, Offa, Kwara State, Nigeria.

Copyright (C) 2021 Author(s) retain the copyright of this article. This article is published under the terms of the Creative Commons Attribution Liscense 4.0.
} 
Praja et al. [16], Seeman and Wankhade [19], Singha and Roys [20] reported significant antibacterial activity of an aqeous extract and attributed it to the combined effect of Andropholides and arabinogalactan proteins.

In contrast, Kowti et al. [18], Seeman and Wankhade [19], Coon [7], Deng [9] investigated the antimicrobial activity using Androgropholia paniculata methanolic and aqeous extracts and authentic andrographolide did not show any activity. Recent research has thrown light on cultivation of this plant on large scale because of its high medicinal value. Hence, the presence investigation was taken up with an objectives to evaluate the antibacterial potential against the micro-organism Chooora et al. [6], Caceres [5] the bioactive compound andrographolide has been reported to be effective in the treatment of upper respiratory tract infection KanoKwan [11]. Andrographis paniculata is also used for other medical purpose. For example, digestive problem, blood cleanser, fever, sore throat Kowti et al. [18]. Andrographis paniculata is used to cure fever and cold and is one of the best antimalaria agents compared to the commercial product of quinine. The herb has shown an ability to reduce inflammation (heat) and fight viral infections and is used as a principal ingredients in traditional Chinese medicinal formular for lung support from colds Singha and Roys [20]. Andrographis paniculata acts to dispel heat and remove toxin. Androgrophaloid was found to be more potent and a standard hepate protective agent Ayak et al. [3], Chang and Butpph [4]. Since ancient times, Andrographis paniculata has been known in traditional Asian medicine as an immune system booster to treat infections in the gastrointestinal tract and upper respiratory tracts, harps, sore throat and a variety of other chronic infectious diseases Praja pati $e t$ al. [16]. Parvataneni and Koduru [14] Reported the antibacterial activity of methanol extract of the leaves of Andrographis paniculata against Staphylococcus auereus, Bacillus substitilis, Streptococcus epidemidis, Eschericia coli, Pneumonia and Pseudomonas aeruginosa. Kowti et al. [18] Reported the antibacterial value of ethanol leaf extract against pathogenic bacteria. Bioactive compound andrapholides was isolated from the leaf, their results revealed that the ethanol leaf extract and andrographolide compound are potent in inhibiting these bacteria and his work highlights that the inhibitory effect is on part with standard antibiotics. Rajalakshmi et al. [10] reported antimicrobial activity of various organic and aqeous extracts of eight months old micro-propagated plantlets of Andrographis paniculata against gram negative bacterials such as Klebsiella Pneumonia, Eschericia coli, Pseudomonas aeruginosa, gram positive Staphylococcus aureus and Bacillus subtilitis bacteria. Flavonoids mainly exist in the root, but have also been isolated from the leaves. The aerial parts contain alkanes, ketones and aldehydes Tapsel et al. [21].

This work is focused on the analysis of the Andrographis extract against the selective micro-organisms. The study is based on primary data obtained by the experiment carried out at Science Laboratory Technology in Federal Polytechnic Offa, Kwara Sate Nigeria, in which the observations or the zones of inhibition (Tn mm) are recorded as data obtained. The broad aim of this work is to study statistically the antibacterial potential of Andrographis peniculata on selective bacteria and compare with normal antibiotics.

\section{Data Presentation and Analysis}

\subsection{Data Presentation}

This aspects preset the data obtained from the level of inhibition of solvent extract of Andrographis paniculata leaf against some selective bacterial.

Table 1 The level of inhibition of bacteria isolate on methanolic extract of Andrographis paniculata leaf

\begin{tabular}{|l|l|l|l|l|l|l|}
\hline \multicolumn{9}{|c|}{ CONCENTRATION (Treatment) } \\
\hline S/N & BACTERIA (Block) & Gram's Reaction & $\begin{array}{l}\text { A } \\
\mathbf{1 0 0} \mathbf{m g} / \mathbf{m l}\end{array}$ & $\begin{array}{l}\text { B } \\
\mathbf{5 0} \mathbf{m g} / \mathbf{m l}\end{array}$ & $\begin{array}{l}\text { C } \\
\mathbf{2 5} \mathbf{m g} / \mathbf{m l}\end{array}$ & $\begin{array}{l}\text { D } \\
\mathbf{1 2 . 5} \mathbf{m g} / \mathbf{m l}\end{array}$ \\
\hline 1 & & & 20.0 & 16.0 & 15.0 & 14.0 \\
\hline 2 & Staphylococcus aureus & Gram positive & 18.0 & 15.0 & 13.0 & 12.0 \\
\hline 3 & Proteus vulgaris & Gram negative & 20.0 & 15.0 & 13.0 & 12.0 \\
\hline 4 & Escherichia coli & Gram negative & 16.0 & 11.0 & 0.0 & 0.0 \\
\hline
\end{tabular}


Table 2 The level of inhibition of Ethanolic extract of Andrographis paniculata leaves against gram positive and Gram negative bacteria

\begin{tabular}{|l|l|l|l|l|l|c|}
\hline \multicolumn{9}{|c|}{ CONCENTRATION (Treatment) } \\
\hline S/N & BACTERIA (Block) & Gram's Reaction & $\begin{array}{l}\text { A } \\
\mathbf{1 0 0} \mathbf{m g} / \mathbf{m l}\end{array}$ & $\begin{array}{l}\text { B } \\
\mathbf{5 0} \mathbf{m g} / \mathbf{m l}\end{array}$ & $\begin{array}{l}\text { C } \\
\mathbf{2 5} \mathbf{m g} / \mathbf{m l}\end{array}$ & $\begin{array}{l}\text { D } \\
\mathbf{1 2 . 5} \mathbf{m g} / \mathbf{m l}\end{array}$ \\
\hline 1 & & & 20.0 & 18.0 & 15.0 & 14.0 \\
\hline 2 & Staphylococcus aureus & Gram Positive & 20.0 & 15.0 & 14.0 & 12.0 \\
\hline 3 & Proteus vulgaris & Gram Negative & 19.0 & 18.0 & 16.0 & 14.0 \\
\hline 4 & Escherichia coli & Gram Negative & 15.0 & 0.0 & 0.0 & 0.0 \\
\hline
\end{tabular}

Table 3 The level of inhibition of Acetic acid extract of Andrographis paniculata leaves against gram positive and Gram negative bacteria

\begin{tabular}{|c|c|c|c|c|c|c|}
\hline \multicolumn{7}{|c|}{ CONCENTRATION (Treatment) } \\
\hline $\mathbf{S} / \mathbf{N}$ & BACTERIA (Block) & Gram's Reaction & $\begin{array}{l}A \\
100 \mathrm{mg} / \mathrm{ml}\end{array}$ & $\begin{array}{l}\text { B } \\
50 \mathrm{mg} / \mathrm{ml}\end{array}$ & $\begin{array}{l}\text { C } \\
25 \mathrm{mg} / \mathrm{ml}\end{array}$ & $\begin{array}{l}\text { D } \\
12.5 \mathrm{mg} / \mathrm{ml}\end{array}$ \\
\hline 1 & Staphylococcus aureus & Gram positive & 16.0 & 14.0 & 12.0 & 10.0 \\
\hline 2 & Staphylococcus aureus & Gram positive & 17.0 & 16.0 & 15.0 & 12.0 \\
\hline 3 & Proteus vulgaris & Gram negative & 24.0 & 20.0 & 18.0 & 16.0 \\
\hline 4 & Escherichia coli & Gram negative & 0.0 & 0.0 & 0.0 & 0.0 \\
\hline
\end{tabular}

Table 4 The level of inhibition of Acetone extract of Andrographis paniculata leaves against gram positive and Gram negative bacteria

\begin{tabular}{|c|c|c|c|c|c|c|}
\hline \multicolumn{7}{|c|}{ CONCENTRATION (Treatment) } \\
\hline $\mathbf{S} / \mathbf{N}$ & BACTERIA (Block) & Gram's Reaction & $\begin{array}{l}A \\
100 \mathrm{mg} / \mathrm{ml}\end{array}$ & $\begin{array}{l}\text { B } \\
50 \mathrm{mg} / \mathrm{ml}\end{array}$ & $\begin{array}{l}\text { C } \\
25 \mathrm{mg} / \mathrm{ml}\end{array}$ & $\begin{array}{l}\text { D } \\
12.5 \mathrm{mg} / \mathrm{ml}\end{array}$ \\
\hline 1 & Staphylococcus aureus & Gram positive & 18.0 & 16.0 & 15.0 & 14.0 \\
\hline 2 & Staphylococcus aureus & Gram positive & 15.0 & 14.0 & 12.0 & 10.0 \\
\hline 3 & Proteus vulgaris & Gram negative & 15.0 & 14.0 & 12.0 & 10.0 \\
\hline 4 & Escherichia coli & Gram negative & 19.0 & 0.0 & 0.0 & 0.0 \\
\hline
\end{tabular}


Table 5 The level of inhibition of selective antibiotics against some bacteria

\begin{tabular}{|c|c|c|c|c|c|c|}
\hline \multicolumn{6}{|c|}{ Bacteria (Observation Block) } & \multirow[b]{2}{*}{$\begin{array}{l}\text { Antibiotic } \\
\text { response }\end{array}$} \\
\hline $\mathbf{S} / \mathbf{N}$ & $\begin{array}{l}\text { ANTIBIOTICS } \\
\text { (Treatment) }\end{array}$ & $\begin{array}{l}\text { Proteus } \\
\text { vulgaris }\end{array}$ & $\begin{array}{l}\text { Escherichia } \\
\text { Coli }\end{array}$ & $\begin{array}{l}\text { Staphylococcus } \\
\text { aureus }\end{array}$ & $\begin{array}{l}\text { Streptococcus } \\
\text { Pyogenes }\end{array}$ & \\
\hline 1 & AMX & 0.0 & 14.0 & 0.0 & 5.0 & 4.75 \\
\hline 2 & ERY & 0.0 & 10.0 & 6.0 & 6.0 & 5.50 \\
\hline 3 & CPX & 2.0 & 0.0 & 8.0 & 6.0 & 4.00 \\
\hline 4 & COT & 0.0 & 0.0 & 0.0 & 0.0 & 0.00 \\
\hline 5 & PT & 8.0 & 0.0 & 8.0 & 7.0 & 5.75 \\
\hline 6 & GEN & 2.0 & 0.0 & 11.0 & 8.0 & 5.25 \\
\hline 7 & CRO & 8.0 & 0.0 & 0.0 & 0.0 & 2.00 \\
\hline 8 & CHL & 3.0 & 0.0 & 0.0 & 0.0 & 0.75 \\
\hline 9 & STR & 0.0 & 0.0 & 6.0 & 0.0 & 1.50 \\
\hline 10 & OFL & 7.0 & 10.0 & 8.0 & 5.0 & 7.50 \\
\hline 11 & $\begin{array}{l}\text { Andrographis } \\
\text { paniculata }\end{array}$ & 15.4 & 14.4 & 16 & 3.8 & 12.40 \\
\hline \multicolumn{2}{|c|}{ Bacteria Mean Response } & 4.1 & 4.4 & 5.7 & 3.7 & 4.5 \\
\hline
\end{tabular}

AMX = Amoxylin, ERY = Erthromycin, COT $=$ Cotrimoxazole, $\mathrm{GEN}=$ Genetamycin, $\mathrm{CHL}=$ Chloraphenicol, STR $=$ Streptomycin, $\mathrm{OFL}=$ Ofloxacin, $\mathrm{CRO}=$ Ceftriaxone, Etc

\subsection{Data analysis and results}

Table 6 Two-Way Anova of Level of Inhibition of Methanolic Extract of Andrographis paniculata Leaf against the selective Bacteria

\begin{tabular}{|l|l|l|l|l|l|}
\hline \multicolumn{6}{|l}{ Two-way ANOVA: observation versus methanolic extract, bacteria } \\
\hline Source & DF & SS & MS & F & P \\
\hline $\begin{array}{l}\text { Methanolic } \\
\text { extract }\end{array}$ & 3 & 206.25 & 68.7500 & 9.07 & 0.004 \\
\hline Bacteria & 3 & 223.25 & 74.4167 & 9.81 & 0.003 \\
\hline Error & 9 & 68.25 & 7.5833 & & \\
\hline Total & 15 & 497.75 & & & \\
\hline
\end{tabular}

At $5 \%$ level of significant, $p(0.004)<0.05$ in table 6 , a column reject Ho and conclude that the means of the methanolic extract against the bacteria are significant.

Interpretation: The table 6 indicate that the means of mathanolic extract fractions of $(100 \mathrm{mg} / \mathrm{ml}, 50 \mathrm{mg} / \mathrm{ml}, 25 \mathrm{mg} / \mathrm{ml}$, $12.5 \mathrm{mg} / \mathrm{ml}$ ) against the selective Bacteria (Staphylococcus aureus, Streptococcus pyogenes, Proteus vulgaris, Escherichia coli) are significantly different.

According to the two-way analysis in table 6, it reflects that the efficacy of methanolic extract of Andrographis paniculata leaves against the bacteria are significantly difference having $\mathrm{p}$ values $<0.05$ 
Table 7 Two-Way Anova of Level of Inhibition of Ethanolic Extract of Andrographis paniculata Leaves against the selective Bacteria

\begin{tabular}{|l|l|l|l|l|l|}
\hline \multicolumn{6}{|l|}{ Two-way ANOVA: observation versus ethanolic extract, bacteria } \\
\hline Source & DF & SS & MS & F & P \\
\hline Ethanoli extract & 3 & 169.25 & 56.417 & 7.08 & 0.010 \\
\hline Bacteria & 3 & 474.75 & 158.250 & 19.85 & 0.000 \\
\hline Error & 9 & 71.75 & 7.972 & & \\
\hline Total & 15 & 715.75 & & & \\
\hline \multicolumn{7}{|l|}{ S $=2.824$ R-Sq $=89.98 \%$ R-Sq(adj) $=83.29 \%$} \\
\hline
\end{tabular}

At $5 \%$ level of significance, $p(0.010)<0.05$ in table7, reject Ho and conclude that the means of the ethanolic extract against the bacteria are significant.

Interpretation: The table 7 indicate that the means of ethanolic extract fractions of $(100 \mathrm{mg} / \mathrm{ml}, 50 \mathrm{mg} / \mathrm{ml}, 25 \mathrm{mg} / \mathrm{ml}$, $12.5 \mathrm{mg} / \mathrm{ml}$ ) against the Bacteria (Staphylococcus aureus, Streptococcus pyogenes, Proteus vulgaris, Escherichia coli) are significantly different.

According to the two-way analysis above it reflect that the efficacy of ethanolic extract of Andrographis paniculata leaves against the Bacteria are significantly difference having $\mathrm{p}$-values $<0.05$.

Table 8 Two-Way Anova of Level of Inhibition of Acetic Acid Extract of Andrographis paniculata Leaves against some Bacteria

\begin{tabular}{|l|l|l|l|l|l|}
\hline \multicolumn{7}{|l|}{ Two-way ANOVA: observation versus acetic acid extract, bacteria } \\
\hline Source & DF & SS & MS & F & P \\
\hline Acetic acid extract & 3 & 48.25 & 16.083 & 6.98 & 0.010 \\
\hline Bacteria & 3 & 840.75 & 280.250 & 121.55 & 0.000 \\
\hline Error & 9 & 20.75 & 2.306 & & \\
\hline Total & 15 & 909.75 & & & \\
\hline \multicolumn{7}{|c|}{ S $=1.518$ R-Sq $=97.72 \%$ R-Sq(adj) $=96.20 \%$} \\
\end{tabular}

At $5 \%$ level of significance, $\mathrm{p}(0.010)<0.05$ in table 8, reject Ho and conclude that the means of the acetic acid extract against the Bacteria are significant.

Interpretation: The table 8 indicate that the means of acetic acid extract fractions of $(100 \mathrm{mg} / \mathrm{ml}, 50 \mathrm{mg} / \mathrm{ml}, 25 \mathrm{mg} / \mathrm{ml}$, $12.5 \mathrm{mg} / \mathrm{ml}$ ) against the Bacteria (Staphylococcus aureus, Streptococcus pyogenes, Proteus vulgaris, Escherichia coli) are significantly different.

According to the analysis above, it reflect that the efficacy of acetic acid extract of Andrographis paniculata leaves against the Bacteria are significantly difference having $\mathrm{p}$-values $<0.05$.

Table 9 Two-Way Anova of Level of Inhibition of Acetone Extract of Andrographis paniculata Leaves against some Bacteria

\begin{tabular}{|c|c|c|c|c|c|}
\hline \multicolumn{6}{|c|}{$\begin{array}{l}\text { Two-way ANOVA: observation versus acetone extract, } \\
\text { bacteria }\end{array}$} \\
\hline Source & DF & SS & MS & $\mathbf{F}$ & $\mathbf{P}$ \\
\hline $\begin{array}{l}\text { Acetone } \\
\text { extract }\end{array}$ & 3 & 159.5 & 53.1667 & 3.20 & 0.077 \\
\hline Bacteria & 3 & 267.0 & 89.0000 & 5.36 & 0.022 \\
\hline Error & 9 & 149.5 & 16.6111 & & \\
\hline Total & 15 & 576.0 & & & \\
\hline
\end{tabular}


At $5 \%$ level of significance, p (0.077) $>0.05$ in table 9 , do not reject Ho and conclude that the means of acetone extract against the bacteria are not significant.

Interpretation: The table 9 indicate that the means of acetone extract fractions of $(100 \mathrm{mg} / \mathrm{ml}, 50 \mathrm{mg} / \mathrm{ml}, 25 \mathrm{mg} / \mathrm{ml}$, $12.5 \mathrm{mg} / \mathrm{ml}$ ) against the bacteria (Staphylococcus aureus, Streptococcus pyogenes, Proteus vulgaris, Escherichia coli) are not significantly different.

According to the analysis, it rejects that the potency of acetone extract of Andrographis paniculata leaves against the bacteria are not significantly difference having $p$-values $>0.05$

Table 10 Two-Way Anova of Level of Inhibition of selective Antibiotic against some Bacteria

\begin{tabular}{|l|l|l|l|l|l|}
\hline \multicolumn{6}{|l|}{ Two-way ANOVA: Response versus Antibiotics, bacteria } \\
\hline Source & DF & SS & MS & F & P \\
\hline Antibiotics & 10 & 497.64 & 49.7636 & 2.90 & 0.012 \\
\hline Bacteria & 3 & 25.08 & 8.3612 & 0.49 & 0.694 \\
\hline Error & 30 & 514.84 & 17.1612 & & \\
\hline Total & 43 & 1037.56 & & & \\
\hline \multicolumn{7}{|c|}{$\mathrm{S}=4.143 \mathrm{R}-\mathrm{Sq}=50.38 \%$ R-Sq(adj) $=28.88 \%$} \\
\end{tabular}

At $5 \%$ level of significance, $p$ value $(0.012)<0.05$, we reject the null hypothesis. Therefore there is significant difference among the effect of different antibiotics used in the treatment of bacteria diseases.

The p value of bacteria $0.694>0.05$, we do not reject the null hypothesis. Therefore there is no significant difference among the bacteria treated with antibiotics. As such any differences in the effect of antibiotics can be traced to difference in bacteria.

Also, using the mean effect of antibiotics, it can be seen that the mean effect are: $0.00,0.75,1.50,2.00,4.00,4.75,5.25$, 5.50, 5.75, 7.50 and 12.40 for Cotrimoxazole, Chloraphenicol, Streptomycin, Ceftriaxone, CPX, Amoxylin, Gentamycin, ERY, PT, Streptomycin and Andrographis paniculata respectively. Simultaneously, the mean responses of bacteria to antibiotics are: 3.7, 4.1, 4.4 and 5.7 for Streptococcus pyogenes, Proteus vulgaris, Escherichia coli and Staphylococcus aureus, respectively.

\section{Results and discussion}

There has been considerable interest in the use of plant material as an alternative method to control microorganisms and many plants have been showed to be specially targeted against resistance pathogenic bacteria.

Tables 1-4 was on the level of inhibition exhibited by the Bacteria on the different solvent extract of Andrographis paniculata. Table 1 was on the methanolic extract level of inhibition, table 2 was on the ethanolic extract, table 3 was on the Acetic acid extract while table 4 was on the Acetone extract level of inhibition. The Bacteria are Staphylococcus aureus, Streptococcus pyogenes, proteus vulgaris and Escherichia coli. Table 5 was on the level of inhibition of selected antibiotics against some bacteria with the Antibiotics Means of response and also Bacteria Means response.

Table 6 was on the two-way analysis of variance on methanolic extract of Andrographis paniculata against the some Bacteria where the p-values is 0.004. Table 7 was on the two-way analysis on ethanolic extract of Andrographis paniculata leaves against the Bacteria where the p-values is 0.010. Table 8 was on the two-way ANOVA of acetic acid extract of Andrographis leaves against micro-organism where the p-values is 0.010 . Table 9 was on the two-way ANOVA of Acetone extract of Andrographis against the Bacteria where p-values is 0.077 . Table 10 was also on the two-way ANOVA of Antibiotics against the some Bacteria in which p-values is 0.012 . Also, the ranking scores of the mean effect of antibiotics are: 0.00, 0.75, 1.50, 2.00, 4.00, 4.75, 5.25, 5.50, 5.75, 7.50 and 12.40 for Cotrimoxazole, Chloraphenicol, Streptomycin, Ceftriaxone, CPX, Amoxylin, Gentamycin, ERY, PT, Streptomycin and Andrographis paniculata respectively. Andrographis paniculata exceed expectation by actively inhibiting the growth and survival of the various Bacteria. 


\section{Conclusion}

Results obtained from this Analysis showed that Andrographis paniculata leaf extract, exhibited the strongest antimicrobial activity than the control. Andrographis paniculata is concluded to be highly potent in the treatment of some selected bacteria diseases. Also, the study revealed that the effective drugs could be produced from Andrographis paniculata leaves used in traditional medicine. This could lead to development of modern pharmaceutical industries, thereby enhancing self-reliance. More active drugs can be produced to solve the present day problem of drug resistance in the health management.

\section{Compliance with ethical standards}

\section{Acknowledgments}

Thanks to my co-authors for their input toward the success of this publication.

\section{Disclosure of conflict of interest}

The authors declare no conflict of interest.

\section{References}

[1] Anurag Singh, MD Maqsood Ahamood Khan, Deepshicha Sahu, Neelu Vish waka'ma' Anuradha Yadav and Abaidya Nath Singh. Pharmacological and anti-bacterial activities of the leaves Andrographis paniculata Nees. Journal 0f Pharmacognosy and phytochemistry. E 2017; 6(37): 418 - 420.

[2] Anial Kumar o, Mulyala Naidul and Raja Rao KG. Invitro antibacterial activity in the extract of Andrographis paniculata Burm.F. International Journal of fharm Tech Research. CODEM (USA) IJPRIF. April-June 2010; 12(2): 1383-1385.

[3] Ayak BKN, Pavithera S, and Anima (Nada). Soxhlet extraction of leaf extracts of Androgaphis paniculata and its antibacterial efficacy against few pathogenic bacterial straine. Scholar research library. DerpharmaciaLe ttre. 2015; 7(4): 253.188N 0975.5071 USA CODEN: DPLEB4.

[4] Chang Hm, Butpph, pharmacology and application of Chines material medica, Chinese Medicinal material Resaerch center, The Chinese university of Hongkong, Singapul. World scientific publishing C.0. Pto. Ltd 1987.2: 918928

[5] Caceres, DD, Hancke, JL, Burgos, RA and Wikman, GK. Prevention of common cold with Andrographis paniculata dried extract. A pilot double blind trial.phytomedicine. 1997; 101: 104

[6] Chooora RN, Nayar SL, Chopra IC. Glossary of Indian medicinal plants Niscom, SIR,New Delhi. 1956.

[7] Coon JT. Andrographis-paniculata in the treatment of upper respiratory tract infectionA systematic review of safety and efficacy. Planta Med. 2004; 70; 293-298.

[8] Dada-Adegbola Hannah o, Olajide Olalekan and Ajayi Bamidele. Comparative study of Antibacterial activity of juice, Acetone, methanol and ethanol leaf extract. 2014.

[9] Deng WL. Preliminary studies on the pharmacology of the Andrographis paniculata product dihydro andrographolide sodium succinate. Newsletter Chinese Herbal medicine. 1978; 8/26-28.

[10] Rajalakshmi G, Acuna D, Bhuvaneswari B, Venl-atesan RS, Natarajan A, Jegatheesan K. 2012. Holt SMD,Linda c. Miracle Herbs. How herbs combine with modern medicine to treat cancer, Heart disease, AIDS and more, Caro publishing Group. 1998.

[11] KanoKwan J, arukamjorn and Nouo Nemoto journal of health science. 2008; 54(4): 370-881. Pharmacological aspect of Andrographis paniculata on health and its major diterpenoid constitute Andrographolide.

[12] Liu J, Wang JI, Invivo LL and invitro, anti-inflammatory activities of neoandrographolide, The American Journal of Chinese medicine. 2007; 35317-328.

[13] Mislra SK, Sangwan NS and Sangwan RS. Andrographis paniculata (kalmegh). A review pharmacog. Rev. 2007; 1, 283-298. 
[14] Parvataneni R, Koduru RC. Antimicrobial activity of the chloroform extracts of the root and stem. Andrographis paniculata Nees.1nt. Res.J-microbial. 2010; l (2): 37-39.

[15] Pholphana N, Ruchirawat M, Satayavivad J. Determination and variation of three active diterpenoids in Andrographis paniculata (Burm.F.) Nees.phytochem.Anal. 2004; 1(5): 365-371.

[16] Praja Pati ND purohitss, Shanna Al, Kumar T.A hand book of medicinal plants, a complet source Book. Agrobios, Jodhpur, India. 2003; 45-46.

[17] Pavataneni R, Koduru RC. Antimicrobial activity of the chloroform extract of the root and stem. Andrographics Paniculata Needs. Int.Res.J.Microbial. 2010; 2: 37-39.

[18] Kowti R, Harrha R, Gulzar Ahmed M, Harreesh AR; Gowda SS -T, Dinesha R, Satish Kumar BP, Ifran Ali M. Research Journal of pharmaceutical, Biological and chemical science 2010; 3: 691698.

[19] Seeman, Mohod NB, Wankhade SG paturde JT. Effect of plantanig and harvesting date on yield and quality of Kamegh (Andrographis paniculata). J MADS. 2002; 25: 981-983.

[20] Singha PK, Roys, Doysi Antimicrobial activity of Angrograhis paniculata titoterapia 2003; 74: 692-694.

[21] Tapsel LG, Hamphills I, Coblac L, Patile CS, Sullivan DR, Fenach M, Roodenry S, Keogh JB, Clifon DM, Williams PG, Falzio UA, Inge Beki DO. Introduction To Medical Statistics, printed and published in Nigeria by Merit International Printers, Ilorin Kwara Stat. 2002 